\title{
Rapid hepatic clearance of full length CCN-2/CTGF: a putative role for LRP1-mediated endocytosis
}

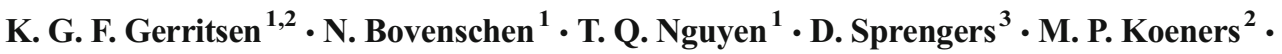 \\ A. N. van Koppen ${ }^{2} \cdot$ J. A. Joles ${ }^{2} \cdot$ R. Goldschmeding ${ }^{1} \cdot$ R. J. Kok ${ }^{4}$
}

Received: 13 July 2016 / Accepted: 8 September 2016 / Published online: 19 September 2016

(C) The Author(s) 2016. This article is published with open access at Springerlink.com

\begin{abstract}
CCN}-2$ (connective tissue growth factor; CTGF) is a key factor in fibrosis. Plasma CCN-2 has biomarker potential in numerous fibrotic disorders, but it is unknown which pathophysiological factors determine plasma CCN-2 levels. The proteolytic amino-terminal fragment of $\mathrm{CCN}-2$ is primarily eliminated by the kidney. Here, we investigated elimination and distribution profiles of full length CCN-2 by intravenous administration of recombinant $\mathrm{CCN}-2$ to rodents. After bolus injection in mice, we observed a large initial distribution volume $(454 \mathrm{~mL} / \mathrm{kg})$ and a fast initial clearance $(120 \mathrm{~mL} / \mathrm{kg} /$ $\mathrm{min})$. Immunosorbent assay and immunostaining showed that CCN-2 distributed mainly to the liver and was taken up by hepatocytes. Steady state clearance in rats, determined by continuous infusion of CCN-2, was fast ( $45 \mathrm{~mL} / \mathrm{kg} / \mathrm{min})$. Renal $\mathrm{CCN}-2$ clearance, determined by arterial and renal vein sampling, accounted for only $12 \%$ of total clearance. Co-infusion of CCN-2 with receptor-associated protein (RAP), an antagonist of LDL-receptor family proteins, showed that RAP prolonged $\mathrm{CCN}-2$ half-life and completely prevented CCN-2 internalization by hepatocytes. This suggests that hepatic uptake of CCN-2 is mediated by a RAP-sensitive mechanism most likely involving LRP1, a member of the LDL-receptor
\end{abstract}

T. Q. Nguyen

T.Q.Nguyen@umcutrecht.nl

1 Department of Pathology, University Medical Center Utrecht, Heidelberglaan 100, 3584, CX Utrecht, The Netherlands

2 Department of Nephrology and Hypertension, University Medical Center Utrecht, Utrecht, The Netherlands

3 Department of Gastroenterology and Hepatology, Erasmus MC University Medical Center, Rotterdam, The Netherlands

4 Department of Pharmaceutics, Utrecht Institute for Pharmaceutical Sciences, Utrecht, The Netherlands family involved in hepatic clearance of various plasma proteins. Surface plasmon resonance binding studies confirmed that CCN-2 is an LRP1 ligand. Co-infusion of CCN-2 with an excess of the heparan sulphate-binding protamine lowered the large initial distribution volume of CCN-2 by $88 \%$ and reduced interstitial staining of CCN-2, suggesting binding of CCN-2 to heparan sulphate proteoglycans (HSPGs). Protamine did not affect clearance rate, indicating that RAP-sensitive clearance of CCN-2 is HSPG independent. In conclusion, unlike its amino-terminal fragment which is cleared by the kidney, full length $\mathrm{CCN}-2$ is primarily eliminated by the liver via a fast RAP-sensitive, probably LRP1dependent pathway.

Keywords Biomarker - CCN-2 - CTGF · Hepatic clearance · LRP1

$\begin{array}{ll}\text { Abbreviations } \\ \text { CCN } & \text { CTGF/CYR61/NOV } \\ \text { CKD } & \text { chronic kidney disease } \\ \text { CTGF } & \text { connective tissue growth factor } \\ \text { CYR61 } & \text { cysteine-rich } 61 \\ \text { E. coli } & \text { Escherichia coli } \\ \text { ELISA } & \text { enzyme-linked immunosorbent assay } \\ \text { ERPF } & \text { effective renal plasma flow } \\ \text { GFR } & \text { glomerular filtration rate } \\ \text { GST-RAP } & \text { glutathione S-transferase-fused } \\ & \text { receptor-associated protein } \\ \text { HSPG } & \text { heparan sulphate proteoglycan } \\ \text { LDL } & \text { low density lipoprotein } \\ \text { LRP } & \text { low density lipoprotein receptor-related protein } \\ \text { NOV } & \text { nephroblastoma overexpressed } \\ \text { PAH } & \text { para-aminohippuric acid } \\ \text { RAP } & \text { receptor-associated protein }\end{array}$




$\begin{array}{ll}\text { SE } & \text { standard error } \\ \text { SEM } & \text { standard error of the mean } \\ \dot{V} & \text { urinary flow rate }\end{array}$

\section{Introduction}

CTGF/CYR61/NOV -2 (CCN-2, also known as connective tissue growth factor or $\mathrm{CTGF}$ ) is a key factor in the pathogenesis of organ fibrosis. Circulating $\mathrm{CCN}-2$ correlates with fibrogenic activity in various chronic disorders and might be useful as a non-invasive marker for monitoring fibrosis, including liver fibrosis (Dendooven et al. 2011; Gressner et al. 2013; Guo-Qiu et al. 2010; Bauer et al. 2012; Honsawek et al. 2013; Colak et al. 2012). The CCN-2 molecule is a 349-amino acid polypeptide of 36-38 kDa which consists of four distinct cysteine-rich interaction domains. Between domain 2 and 3 the protein contains a cysteine-free hinge region, which is susceptible to proteolytic cleavage generating $\mathrm{N}$ - and $\mathrm{C}$-terminal fragments of similar molecular weight. The $\mathrm{N}$-fragment is the predominant $\mathrm{CCN}-2$ molecule in plasma in healthy subjects and chronic kidney disease patients, while full length $\mathrm{CCN}-2$ is hardly detectable by available techniques (Dendooven et al. 2011). In chronic liver disease, however, elevated circulating levels of the full length protein were reported (Gressner et al. 2006; Guo-Qiu et al. 2010). Only sparse data are available on circulating $\mathrm{C}$-fragment levels and reported levels were lower than those of the $\mathrm{N}$-fragment and the full length molecule (Weitz and Usinger 2003; Dziadzio et al. 2005).

Circulating CCN-2 levels are determined by tissue production, release into the circulation, proteolytic cleavage, cell- and matrix interaction and elimination processes. $\mathrm{CCN}-2$ tissue expression is generally increased in chronic fibrotic disorders (Dendooven et al. 2011). However, plasma CCN-2 profiles differ between various disorders perhaps because of different pharmacokinetic profiles of the CCN-2 full-length protein and its fragments and interference with different elimination routes depending on which organ is affected. Previously, we demonstrated that the $\mathrm{N}$-fragment of $\mathrm{CCN}-2$ is primarily eliminated by the kidney resulting in accumulation of circulating $\mathrm{N}$ fragment in chronic kidney disease (CKD) (Gerritsen et al. 2012). The high levels of full length CCN-2 in chronic liver disease and negligible levels in CKD suggest involvement of the liver in clearance of the whole protein. Gao et al. reported in vitro binding of $\mathrm{CCN}-2$ via domain 3 to low density lipoprotein receptor-related protein 1 (LRP1) (Gao and Brigstock 2003), a multifunctional endocytic receptor highly expressed in liver and known to be involved in cellular uptake and subsequent degradation of various proteins (Lillis et al. 2008). Liver cirrhosis is associated with decreased expression of LRP1 (Hollestelle et al. 2004). Low levels of full length CCN-2 in healthy subjects might also be explained by binding to cell surface or matrix. Previous reports show in vitro binding of CCN-2 to heparan sulphate proteoglycans (HSPGs) (Gao and Brigstock 2004). Since HSPGs are widely distributed, full length $\mathrm{CCN}-2$ released into the circulation might be rapidly captured by HSPGs and removed from plasma.

To investigate elimination and distribution profile of full length CCN-2, we administered recombinant human full length CCN-2 intravenously to rodents. In addition, we examined the involvement of LRP1 and HSPGs in clearance and distribution of full length CCN-2 by co-infusion of competing ligands.

\section{Materials and methods}

\section{Proteins}

Recombinant $\mathrm{CCN}-2 \mathrm{~s}$ and anti- $\mathrm{CCN}-2$ antibodies were supplied by FibroGen Inc. (San Francisco, CA). The recombinant human $\mathrm{CCN}-2 \mathrm{~s}$ were produced in a baculovirus expression system in Chinese Hamster Ovary cell lines cultured in hollowfiber fermentors. The proteins were purified by CCN-2-affinity and cation exchange chromatography. Recombinant full length CCN-2 comprised all four domains, the N-terminal fragment comprised domain 1 and 2 and $\mathrm{C}$-terminal fragment comprised domain 3 and 4. Purified placenta-derived LRP1 was a kind gift by Dr. S. K. Moestrup (University of Aarhus, Aarhus, Denmark) (Moestrup and Gliemann 1991). The bacterial vector encoding glutathioneS-transferase-fused receptorassociated protein was kindly provided by Dr. J. Kuiper (Leiden University, Leiden, The Netherlands). Glutathione S-transferase-fused receptor-associated protein (GST-RAP) was expressed in E. coli strain DH5 $\alpha$ and purified by glutathione-Sepharose (Herz et al. 1991).

\section{Animal experiments}

Pharmacokinetic studies were performed in mice and rats. All experiments were approved by the Animal Ethical Committee of the University of Utrecht and performed in accordance with national guidelines for the care and handling of animals. $\mathrm{C} 57 \mathrm{Bl} / 6 \mathrm{~J}$ mice (12 weeks old; Harlan, Horst, The Netherlands) received recombinant human $\mathrm{CCN}-2$ by tail vein injection $(25 \mathrm{pmol} / \mathrm{g}$ bodyweight, single dose) (Gerritsen et al. 2010). A blood sample was drawn by cheek puncture to determine the initial plasma concentration in each individual mouse. To evaluate the plasma disappearance and uptake in organs, mice were sacrificed at various time points ( $n=2$ per time point). Kidneys, liver, lungs, heart and spleen were harvested, weighed, and processed for ELISA or immunohistochemistry, as described below. To evaluate the effects of blocking of LRP1 or HSPGs two separate groups of mice received either GST-RAP $(0.7 \mathrm{nmol} / \mathrm{g}$ bodyweight, $n=8$ ) or protamine hydrochloride (ICN 
Biomedicals, Zoetermeer, The Netherlands) $(5 \mathrm{nmol} / \mathrm{g}$ bodyweight, $n=7$ ), respectively, or vehicle ( $n=6$ for both experiments) by tail vein injection $1 \mathrm{~min}$ before $\mathrm{CCN}-2$ injection in the other tail vein ( $25 \mathrm{pmol} / \mathrm{g}$ bodyweight). Previous reports showed that these amounts of RAP and protamine were adequate to saturate LRP1 and to block HSPGs sufficiently to influence the pharmacokinetics of its ligands, respectively (Saenko et al. 1999; Gerritsen et al. 2010; Narita et al. 1995).

Studies in rats were performed to quantify renal and nonrenal CCN-2 clearance. Male Wistar-Kyoto rats (15-17 weeks old; Harlan) were anaesthetized and instrumented as described (Gerritsen et al. 2010). After a 45 min stabilization period, infusion of full length $\mathrm{CCN}-2$ was started at $54 \mathrm{pmol} / \mathrm{kg} /$ min, based on pilot clearance studies. Inulin (Inutest, Fresenius Pharma, Linz, Austria) and PAH (Sigma, St Louis, $\mathrm{MO}$ ) were infused for renal clearance measurements. Urine was collected at 15 min intervals. 90 Min after the start of CCN-2 infusion two arterial blood samples were taken at an interval of $30 \mathrm{~min}$. After a short equilibration period a third arterial blood sample was taken simultaneously with puncture of the left renal vein to determine renal extraction and clearance. Inulin and PAH were measured as described (Verseput et al. 1997).

\section{CCN-2 enzyme-linked immunosorbent assay}

Recombinant human $\mathrm{CCN}-2$ levels in plasma, urine, and tissue homogenates were determined by sandwich enzyme-linked immunosorbent assay (ELISA), detecting both full length $\mathrm{CCN}-2$ and the N-terminal fragment. A human $\mathrm{CCN}-2$ specific assay was used, that does not cross-react with rodent $\mathrm{CCN}-2$, as described (Gerritsen et al. 2010; Gerritsen et al. 2015). Frozen renal tissue (stored at $-80{ }^{\circ} \mathrm{C}$ ) was homogenized in lysis buffer (20 mM Tris (Roche, Mannheim, Germany), $150 \mathrm{mM}$ $\mathrm{NaCl}$ (Merck, Darmstadt, Germany), $1 \%$ Triton X-100, $10 \%$ glycerol, 1 mM EDTA (Riedel-de Haen, Seelze, Germany), $0.1 \%$ SDS (Research Organics, Cleveland, $\mathrm{OH}), 1 \mathrm{mM}$ EGTA, $0.5 \%$ sodium deoxycholate, $50 \mathrm{mM}$ $\mathrm{NaF}, 2 \mathrm{mM}$ Na-orthovanadate (Sigma), $\mathrm{pH}$ 7.4) containing $5 \%$ Protease Inhibitor Cocktail (Sigma). Microtiter plates (Maxisorb; Nunc, Roskilde, Denmark) were coated with capture anti- CCN-2 monoclonal antibody $(5 \mu \mathrm{g} / \mathrm{ml}$; FibroGen). Subsequently, diluted samples and standards (recombinant human CCN-2; FibroGen) were added and incubated with non-cross-blocking human anti- $\mathrm{CCN}-2$ monoclonal antibody conjugated directly to alkaline phosphatase $(0.5 \mu \mathrm{g} / \mathrm{ml}$; FibroGen). Para-nitrophenylphosphate (Sigma) was used as substrate for the colorimetric reaction. Assay sensitivity (lower limit of detection) was $20 \mathrm{pmol} / \mathrm{L}$. Intra- and interassay coefficients of variation were below $10 \%$.

\section{Immunofluorescence}

Immunostaining for CCN-2 was performed on $3 \mu \mathrm{m}$ formalinfixed paraffin-embedded tissue sections. After deparaffinization, antigen retrieval was performed by predigestion with Protease XXIV (0.2 M phosphate; Sigma) followed by blocking of endogenous peroxidase activity $\left(1 \% \mathrm{H}_{2} \mathrm{O}_{2}\right.$ in phosphate/citrate buffer). Sections were incubated with $\mathrm{CCN}$-2-specific human monoclonal antibody (FibroGen) $(24 \mu \mathrm{g} / \mathrm{ml}$ in PBS/1 \% BSA) for $1 \mathrm{~h}$ followed by incubation with rabbit anti-human IgG (Dako, Glostrup, Denmark) (1:100, $30 \mathrm{~min})$. Amplification was performed with Powervision poly-peroxidase goat anti-rabbit IgG (Klinipath, Duiven, The Netherlands) (30 min) and FITC Tyramide Amplification Reagent (PerkinElmer, Boston, MA) (1:50, $10 \mathrm{~min}$ ). TO-PRO 3 Iodide (Molecular Probes, Eugene, OR) was used for nuclear counterstaining. Slides were mounted in Vectashield (Vector Laboratories, Ontario, Canada), and visualized by fluorescence and confocal laser scanning microscopy. For all stainings, incubation with secondary antibody alone served as a negative control.

\section{Surface Plasmon resonance analysis}

Real-time binding experiments were performed on the Biacore T100 (GE Healthcare, Uppsala, Sweden). LRP1 was immobilized on a Series S CM5 sensor-chip surface at 3.4 $\mathrm{fmol} / \mathrm{mm} 2$. One control flow channel was routinely activated and blocked in the absence of protein. Association of recombinant human CCN-2 and its proteolytic fragments and inhibition by RAP were assessed in $10 \mathrm{mM}$ Hepes ( $\mathrm{pH} 7.4$ ), $150 \mathrm{mM} \mathrm{NaCl}, 5 \mathrm{mM} \mathrm{CaCl} 2$ and $0.005 \%$ surfactant P20 for $2 \mathrm{~min}$, at a flow rate of $20 \mu \mathrm{l} / \mathrm{min}$ at $25^{\circ} \mathrm{C}$. Dissociation was allowed for $2 \mathrm{~min}$ in the same buffer flow. Sensor chips were regenerated using EDTA $125 \mathrm{mM}, \mathrm{NaCl} 0.5 \mathrm{M}$ during at a flow rate of $20 \mu \mathrm{l} / \mathrm{min}$ for $30 \mathrm{~s}$. Proteins were injected until binding equilibrium was reached. Data were corrected for both refractive index changes and were analyzed with BIAcore T100 evaluation software (version 2.01). Affinity constants were determined by steady-state analysis. The inhibitory effect of RAP on the interaction of CCN-2 with LRP1 was assessed by adding RAP $(3 \mu \mathrm{M})$ to immobilized LRP1 followed by CCN-2 $(1 \mu \mathrm{M})$. Subsequently, binding of CCN-2 to RAP-saturated LRP1 was compared with that of $\mathrm{CCN}-2$ $(1 \mu \mathrm{M})$ to LRP1 in the absence of RAP.

\section{Calculations and statistics}

Data are expressed as mean $\pm \mathrm{SE}$ and were compared with Student's $t$-test (2-tailed). Pharmacokinetic analysis was performed using a nonlinear two-compartment model (Multifit program, Department of Pharmacokinetics and Drug Delivery, University of Groningen, The Netherlands) (Prakash et al. 2006). Renal clearances of inulin and PAH 
were calculated by standard formulae. Total CCN-2 clearance was calculated as follows:

infusion rate

$\overline{\text { arterial concentration }}$

Renal vein concentration was used to determine the amount of CCN-2 extracted by the kidney and renal CCN-2 clearance was calculated as follows:

$\underline{(\text { arterial concentration } \times \mathrm{ERPF})-(\text { renal vein concentration } \times(\mathrm{ERPF}-\dot{\mathrm{V}}))}$

arterial concentration

where ERPF is the effective renal plasma flow and $\dot{V}$ the urinary flow rate.

\section{Results}

\section{Circulating full length $\mathrm{CCN}-2$ is primarily eliminated by hepatic metabolism}

First, we investigated the pharmacokinetic profile of recombinant human $\mathrm{CCN}-2$ that was administered intravenously as a single bolus to healthy mice. Human $\mathrm{CCN}-2$ specific antibodies were used to distinguish recombinant human $\mathrm{CCN}-2$ from endogenous $\mathrm{CCN}-2$. The plasma disappearance curve is shown in Fig. 1a. The initial distribution volume was relatively large for a hydrophilic protein such as CCN-2: $454 \pm 47 \mathrm{~mL} /$ $\mathrm{kg}$. This value exceeds plasma and extracellular fluid volume suggesting tissue binding of CCN-2. The plasma disappearance rate during the first 15 min was fast with an initial clearance of $120 \pm 11 \mathrm{~mL} / \mathrm{kg} / \mathrm{min}$ corresponding to an initial halflife of $2.6 \pm 0.02 \mathrm{~min}$. Since plasma levels dropped rapidly to very low levels, no reliable pharmacokinetic data could be obtained after the initial distribution phase. To obtain a more accurate estimate of $\mathrm{CCN}-2$ clearance and to quantify renal and non-renal clearance, additional experiments were conducted with continuous CCN-2 infusion. Because we had to take multiple blood samples, we performed these experiments in anaesthetized rats. After reaching steady state, kinetic parameters were calculated from plasma concentrations and urinary excretion, as summarized in Table 1. Total CCN-2 clearance was derived from steady state plasma concentration and infusion rate. For determination of renal extraction and clearance, blood samples were drawn simultaneously from the renal vein and femoral artery. Total CCN-2 clearance was $45 \pm 8 \mathrm{~mL} / \mathrm{kg} / \mathrm{min}$ with renal clearance $5.4 \pm 0.8 \mathrm{~mL} / \mathrm{kg} / \mathrm{min}$, accounting for only $\sim 12 \%$ of total clearance, indicating that the majority of the protein was cleared via a non-renal route.

To investigate $\mathrm{CCN}-2$ tissue distribution we measured $\mathrm{CCN}-2$ tissue levels and performed immunohistochemistry after single bolus injection in mice. We observed rapid accumulation of CCN-2 in the liver and to a lesser extent in the kidney (Fig. 1b-d). Immunofluorescent staining showed uptake of CCN-2 in intracellular organelles in hepatocytes (Fig. 1e), which was observed only temporarily during the first 15 min after injection suggestive of rapid hepatic metabolism. In the kidney, CCN-2 was filtered and subsequently endocytosed to a large extent by proximal tubular cells, as reported previously (Gerritsen et al. 2010). We found practically no distribution to other tissues including lung, heart or spleen. Thus, in healthy rodents circulating full length $\mathrm{CCN}-2$ is primarily eliminated by the liver and to a lesser extent by the kidney.

\section{RAP prolongs $\mathrm{CCN}-2$ half-life and prevents $\mathrm{CCN}-2$ internalization by hepatocytes}

We studied the effect of RAP, an antagonist of low density lipoprotein receptor (LDLR) family proteins, on the pharmacokinetic profile of CCN-2. In mice, intravenous injection of an excess of GST-RAP 1 min prior to intravenous bolus injection of $\mathrm{CCN}-2$ reduced elimination rate of $\mathrm{CCN}-2$ after a comparable initial distribution phase (Fig. 2a), resulting in 5-fold higher plasma CCN-2 concentrations at $10-15 \mathrm{~min}$ after injection $(p<0.001)$. Immunohistochemistry showed less uptake in intracellular organelles in hepatocytes, suggesting reduced intrahepatic degradation (Fig. 2b). These results suggest that hepatic metabolism of circulating $\mathrm{CCN}-2$ is dependent on its uptake in hepatocytes by an LDLR family member, most likely LRP1. RAP has high affinity for LRP1 $\left(\mathrm{K}_{d} 5.4 \mathrm{nM}\right)$ and is known to inhibit binding and endocytosis of all known LRP1 ligands (Williams et al. 1992). Administration of a bolus GST-RAP alone did not result in detectable levels of circulating endogenous full length $\mathrm{CCN}-2$ 15 min after injection (data not shown). This indicates that $\mathrm{CCN}-2$ release from tissues is very low in healthy mice.

To confirm that CCN-2 is an LRP1 ligand, we performed surface plasmon resonance analysis with immobilized LRP1. $\mathrm{CCN}-2$ bound to LRP1 in a dose-dependent manner (Fig. 2c). The binding affinity $\left(K_{d}\right)$ of this interaction was calculated to be $116 \pm 22 \mathrm{nM}$. Interaction of CCN-2 with LRP1 was at least partially inhibited by RAP (Fig. 2d). Next, interaction of individual proteolytic CCN-2 fragments with LRP1 was analyzed. Interestingly, the C-terminal part of CCN-2 interacted with LRP1 $\left(K_{d}=112 \pm 7 \mathrm{nM}\right)$ with similar affinity as did fulllength $\mathrm{CCN}-2$. In contrast the N-terminal part of $\mathrm{CCN}-2$ did not show any binding to immobilized LRP1, up to concentrations of $1 \mathrm{uM}$. These data indicate that LRP1 binds to $\mathrm{CCN}-2$ through LRP binding sites in its C-terminal moiety.

\section{Blocking of HSPGs reduces CCN-2 distribution volume in vivo}

To examine how binding of HSPGs in vivo influenced the pharmacokinetic profile of plasma $\mathrm{CCN}-2$, we performed 
Fig. 1 Pharmacokinetic profile after single intravenous dose of recombinant human $\mathrm{CCN}-2$ in mice. a Plasma disappearance curve of $\mathrm{CCN}-2$. Plasma concentration expressed as percentage of injected dose per $\mathrm{mL}$ plasma. Each dot represents one animal. b-c Immunofluorescence of liver $\mathbf{b}$ and kidney $\mathbf{c}, 15 \mathrm{~min}$ after CCN-2 administration, by using human anti- CCN-2 (green), visualized by fluorescence microscopy. d Estimated organ levels expressed as percentage of injected dose of recombinant human $\mathrm{CCN}-2$ 5-10 min after intravenous $\mathrm{CCN}-2$ administration in mice $(n=8)$. e Immunofluorescence of liver by using human anti- $\mathrm{CCN}-2$ (green) and TO-PRO 3 Iodide for nuclear staining (red), visualized by confocal laser scanning microscopy
A

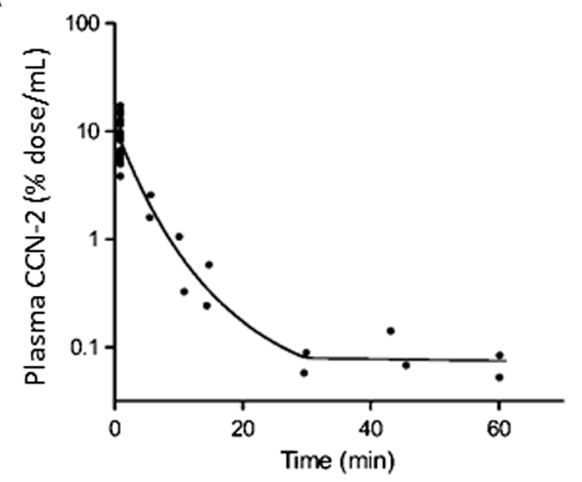

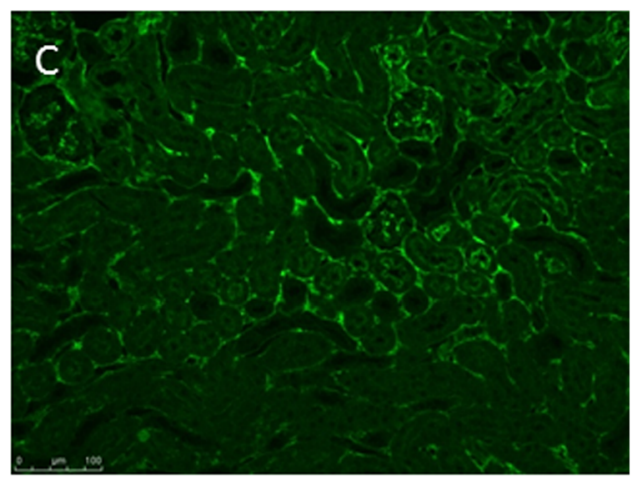

D

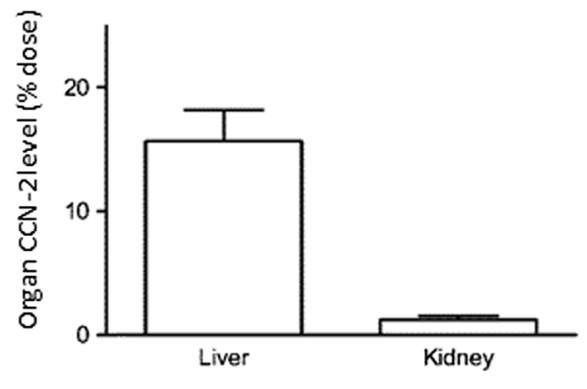

Table 1 Clearance of recombinant human full length $\mathrm{CCN}-2$ in healthy rats

\begin{tabular}{lc}
\hline Parameter & $N=4$ \\
\hline Body weight (g) & $309 \pm 11$ \\
Mean arterial pressure (mmHg) & $101 \pm 2$ \\
GFR (mL/kg/min; inulin) & $9.0 \pm 0.1$ \\
Renal plasma flow (mL/kg/min; PAH) & $30 \pm 1$ \\
Total CCN-2 clearance (mL/kg/min) & $45 \pm 8$ \\
Renal CCN-2 clearance (mL/kg/min) & $5.4 \pm 0.8$ \\
\hline
\end{tabular}

Values are means $\pm \mathrm{SE}$. GFR, glomerular filtration rate; $\mathrm{PAH}$, paraaminohippuric acid clearance studies in the presence of an excess of protamine, which prevents HSPGs from interacting with their ligands (Warshawsky et al. 1996; Narita et al. 1995). Protamine administered as a single dose $1 \mathrm{~min}$ prior to $\mathrm{CCN}-2$ injection resulted in about 7-fold higher plasma CCN-2 levels at all time points as compared to single $\mathrm{CCN}-2$ bolus injection $(p<0.05$, Fig. 3a) and in a decrease of interstitial staining 5 min after bolus injection, in particular in the kidney (Fig. 3b). The parallel shift of the plasma disappearance curve indicates that the distribution volume of $\mathrm{CCN}-2$ was reduced, while clearance remained unaffected by protamine. Thus, binding to HSPGs appears to be involved in distribution of full length $\mathrm{CCN}-2$ but not in its elimination from the circulation. 

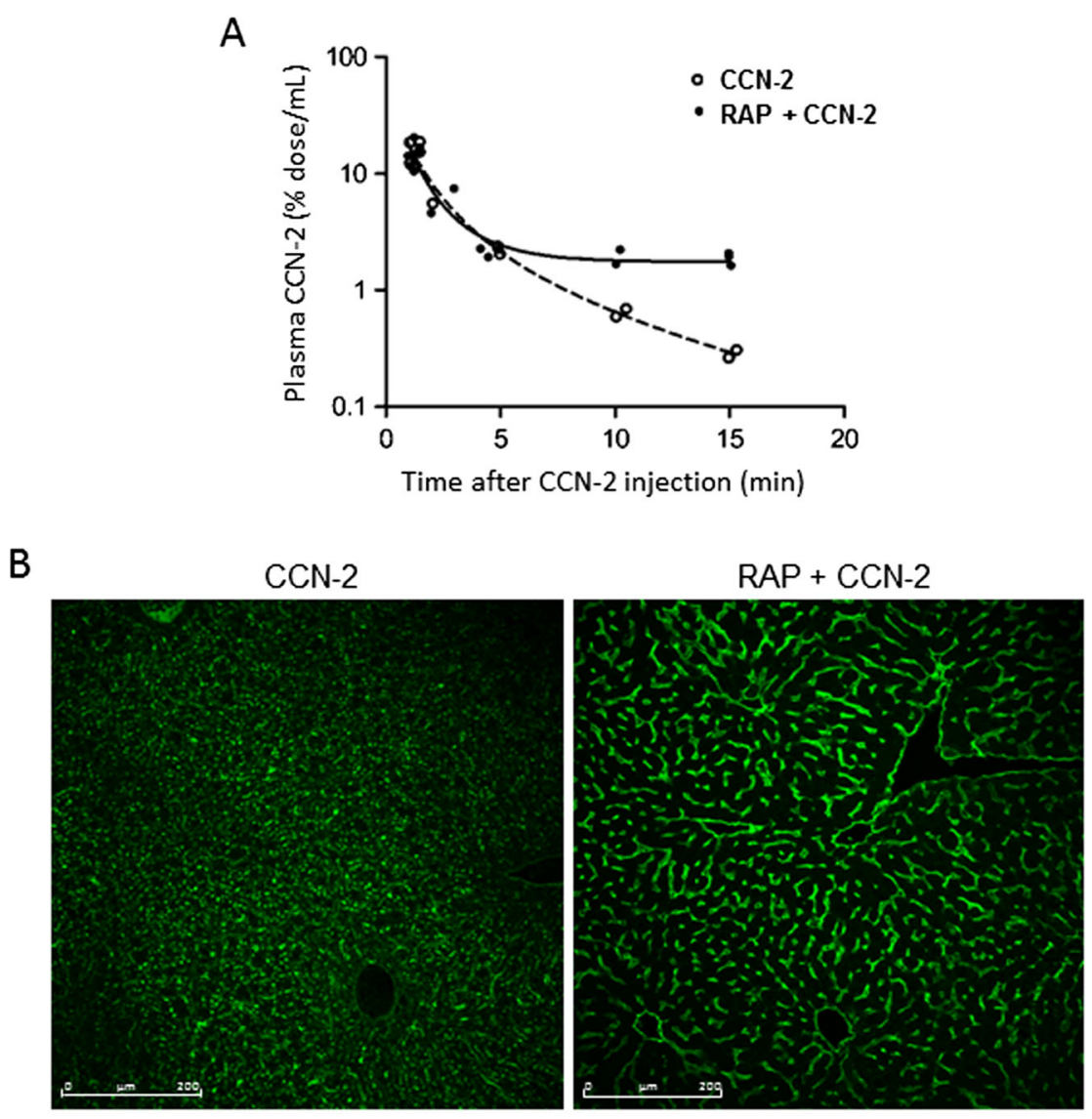

C

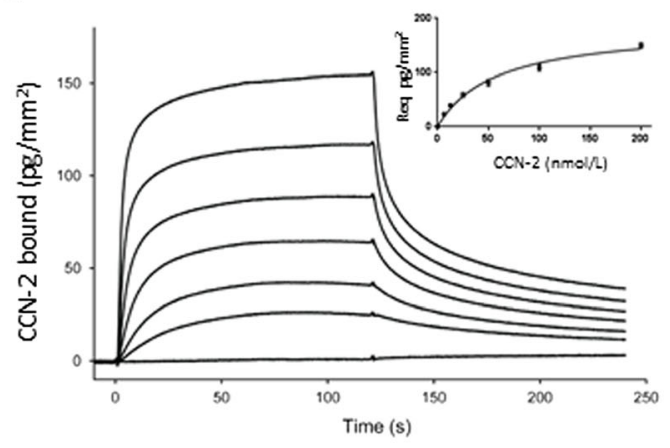

D

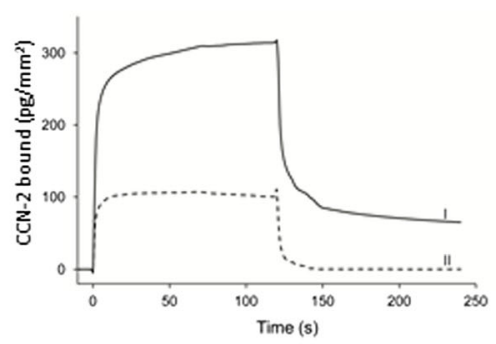

E

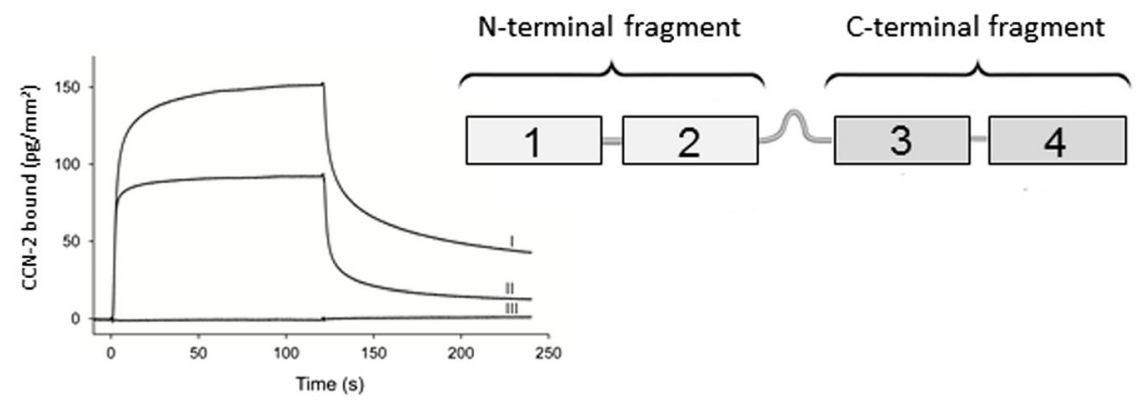


Fig. 2 a-b Pharmacokinetic profile after single intravenous dose of recombinant human $\mathrm{CCN}-2$ preceded by injection of an excess of GSTRAP in mice. a Plasma disappearance curve of CCN-2. GST-RAP prior to $\mathrm{CCN}-2$ reduced the elimination rate but not initial distribution. Plasma concentration is expressed as percentage of injected dose per $\mathrm{mL}$ plasma. Each dot represents one animal. b Immunofluorescence of liver $15 \mathrm{~min}$ after $\mathrm{CCN}-2$ administration, by using human anti- $\mathrm{CCN}-2$ (green), visualized by confocal laser scanning microscopy. GST-RAP prior to CCN-2 (right) reduces uptake in hepatocytes. c-e Surface plasmon resonance analysis of human $\mathrm{CCN}-2$ and its proteolytic fragments, run over immobilized LRP1. Response is depicted as $\mathrm{pg} / \mathrm{mm}^{2}$. c Dosedependent response with concentrations of full length CCN-2 of 0 , $6.25,12.5,25,50,100$ and $200 \mathrm{nM}$. d Interaction of CCN-2 (1 uM) (I) with LRP1 is partially inhibited by GST-RAP (3 uM) (II). e Full length CCN-2 (200 nM) (I) and C-terminal fragment (200 nM) (II), but not Nterminal fragment (200 nM) (III), show interaction with LRP1

\section{A}

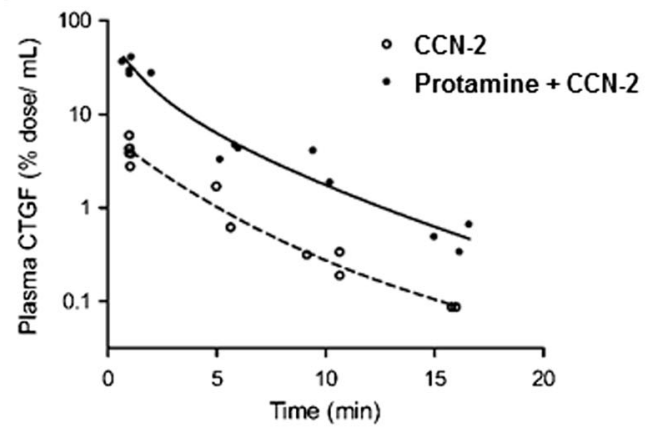

B

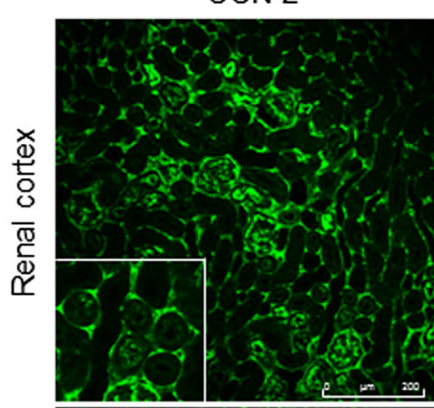

$\mathrm{CCN}-2$

Protamine $+\mathrm{CCN}-2$
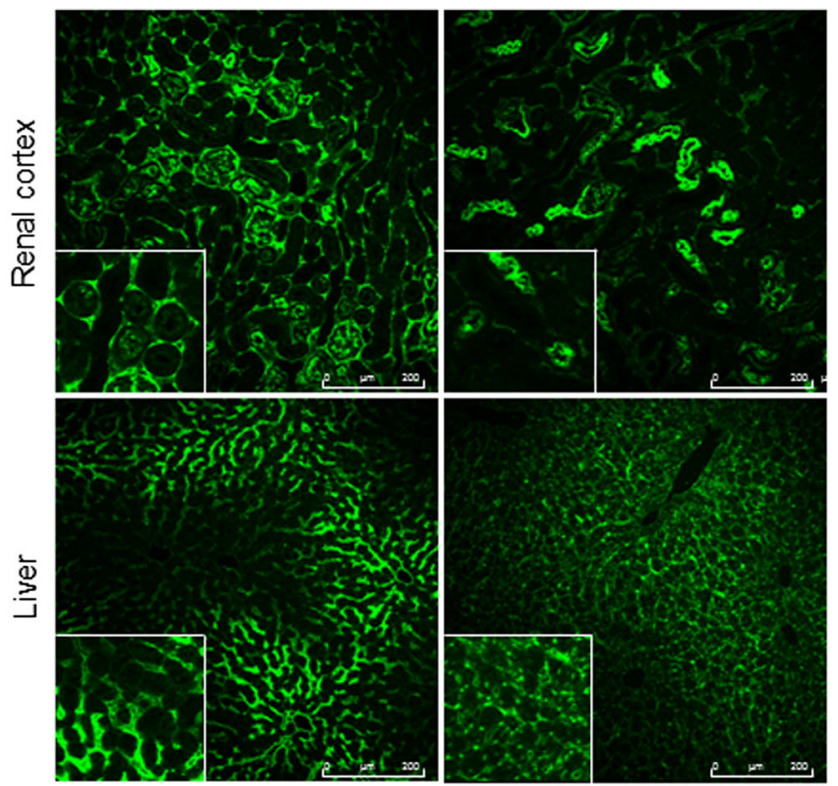

Fig. 3 a-b Pharmacokinetic profile after single intravenous dose of recombinant human $\mathrm{CCN}-2$ preceded by injection of an excess of protamine in mice. a Plasma disappearance curve of $\mathrm{CCN}-2$. Administration of protamine prior to $\mathrm{CCN}-2$ reduced distribution volume but not elimination rate. Plasma concentration is expressed as percentage of injected dose per $\mathrm{mL}$ plasma. Each dot represents one animal. b Immunofluorescence of kidney and liver, 5 min after CCN-2 administration, by using human anti- CCN-2 (green), visualized by confocal laser scanning microscopy. Protamine prior to CCN-2 (right) reduces interstitial staining

\section{Discussion}

The main finding of our studies is that circulating full length CCN-2 is primarily cleared by fast hepatic metabolism via a RAP-sensitive pathway, most likely involving LRP1.

Full length CCN-2 distributed mainly to the liver and was taken up by hepatocytes. The half-life of CCN-2 was markedly prolonged and hepatic uptake substantially reduced after administration of RAP, which suggests that uptake in hepatocytes is mediated by an LDLR family protein. This is in accordance with previous in vitro cell binding experiments, showing that CCN-2 is an LRP1 ligand (Segarini et al. 2001; Gao and Brigstock 2003). We confirmed this by surface plasmon resonance analysis. Rapid disappearance of all intracellular inclusions in hepatocytes $30 \mathrm{~min}$ after bolus injection in mice suggests fast degradation after endocytosis, in line with rapid LRP1-mediated internalization and subsequent intracellular degradation as observed in vitro (Segarini et al. 2001). LRP1 is responsible for plasma clearance of various proteins including coagulation factors and lipoprotein remnants (Lillis et al. 2008). LRP1 is most prominent in liver, but is also present in various other tissues, including lung, central nervous system and lymphoid tissues (Moestrup et al. 1992). Interestingly, mice in which the LRP1 gene is deleted in smooth muscle cells developed aortic dilatation and medial thickening that is accompanied by local accumulation of the $\mathrm{CCN}-2$ protein, indicating that LRP1 maintains the vasculature integrity by modulation of CCN-2 protein levels (Muratoglu et al. 2013). We did not observe evident CCN-2 accumulation in vessels, lung, heart or spleen. Inhibition of LRP1 binding by RAP has been applied before to prove LRP1-involvement in clearance of various LRP1 ligands in vivo (Narita et al. 1995; Saenko et al. 1999; Sarafanov et al. 2001; Schwarz et al. 2000). In addition to LRP1, RAP is known to block ligand binding to other endocytic cell surface receptors of the LDL receptor family members (Bovenschen et al. 2003).

Previous reports found that CCN-2 binds LRP1 via domain 3 , since blocking of LRP1 reduced binding of full length CCN-2 and the C-terminal half, but not binding of domain 4 alone, to activated hepatic stellate cells (Gao and Brigstock 2003). Surface plasmon resonance experiments now confirm that $\mathrm{CCN}-2$ is indeed binding via an epitope on its C-terminal half to LRP1, in agreement with previous pharmacokinetic studies with the N-terminal fragment of CCN-2, that did not show any hepatic uptake in vivo (Gerritsen et al. 2010).

Thus far, elevated plasma levels of full length $\mathrm{CCN}-2$ in chronic liver disease have been considered to be secondary to increased production in fibrotic liver tissue (Gressner et al. 2006; Guo-Qiu et al. 2010). Increased platelet activation in advanced liver disease (Panasiuk et al. 2001) might also contribute to elevated $\mathrm{CCN}-2$, since platelets contain large amounts of full length CCN-2 that is released upon activation (Cicha et al. 2004; Miyazaki et al. 2010). We here show that hepatic metabolism 
is the main elimination route of full length $\mathrm{CCN}-2$. Hence reduced elimination might also contribute to accumulation of full length CCN-2 in advanced liver disease (Kovalenko et al. 2009; Zhang et al. 2009; Guo-Qiu et al. 2010). Hollestelle et al. showed that liver cirrhosis is associated with decreased expression of LRP1 (Hollestelle et al. 2004). However, additional experiments, e.g. elimination studies in experimental liver cirrhosis, would be needed to explore the postulated contribution of reduced hepatic removal to elevated CCN-2 levels in chronic liver disease.

In mice we found a relatively large initial distribution volume exceeding the extracellular fluid volume which is remarkable for a hydrophilic glycosylated protein of approximately $37 \mathrm{kD}$ and suggests tissue or plasma protein binding. Previous studies reported in vitro binding of CCN-2 to HSPGs (Gao and Brigstock 2004), which are widely distributed in all tissues. The substantial decrease in distribution volume of $\mathrm{CCN}-2$ after administration of protamine suggests that $\mathrm{CCN}$ 2 also binds to HSPGs in vivo. This is supported by the finding that interstitial staining in the kidney was markedly reduced after protamine administration, although in the liver this was less evident, possibly as a consequence of $\mathrm{CCN}-2$ binding to other molecules, including LRP1. In vitro, CCN-2 binds to HSPGs via domain 4 on its $\mathrm{C}$-terminal half (Gao and Brigstock 2004). Consistently, interstitial staining in the kidney was virtually absent after in vivo administration of the Nterminal fragment (Gerritsen et al. 2010). Binding to HSPGs has been shown to facilitate LRP1 mediated degradation of the LRP1 ligands factor VIII and tissue activator pathway inhibitor (Sarafanov et al. 2001; Narita et al. 1995; Lillis et al. 2008). However, for CCN-2 we observed no increase of plasma half-life upon blocking its binding to HSPGs by protamine, suggesting that in vivo $\mathrm{CCN}-2$ degradation by LRP1 is not facilitated by binding to HSPGs.

We used antibodies detecting both full length $\mathrm{CCN}-2$ and the $\mathrm{N}$-terminal fragment for immunohistochemistry and ELISA. Although experiments were of short duration, proteolytic cleavage of the full length molecule into its $\mathrm{N}$ - and $\mathrm{C}$-terminal halves could theoretically have influenced the results. This seems unlikely, since in similar experiments with the $\mathrm{N}$-fragment, we observed a much smaller distribution volume, efficient renal clearance and no hepatic uptake at all (Gerritsen et al. 2012). Although we cannot exclude that the small percentage of renal clearance observed upon infusion studies of full length CCN-2 in rats was partly due to $\mathrm{N}$-fragment clearance, some glomerular sieving is also not unlikely for the full length protein that has a diameter of $36-38 \mathrm{kDa}$.

In conclusion, our findings show that full length $\mathrm{CCN}-2$ is primarily eliminated by the liver via a fast RAP-sensitive, probably LRP1-mediated, pathway. The large initial distribution volume of full length $\mathrm{CCN}-2$ is due to a protaminesensitive process, presumably $\mathrm{CCN}-2$ binding to HSPGs, but we have no indication that $\mathrm{CCN}-2$ interaction with HSPGs facilitates RAP-sensitive hepatic catabolism.
Acknowledgments We thank Marcel Fens, Dionne van der Giezen, Willemiek Kassing-van der Ven, Paula Martens, Ebel Pieters, Razi Quadir, Kevin van der Ven and Nel Willekes for technical assistance and support.

Compliance with ethical standards

Disclosures This study was supported by a grant from FibroGen, Inc., a company interested in commercializing anti-CCN-2 therapies. RG has been employed by and has received research support from FibroGen.

Open Access This article is distributed under the terms of the Creative Commons Attribution 4.0 International License (http:// creativecommons.org/licenses/by/4.0/), which permits unrestricted use, distribution, and reproduction in any medium, provided you give appropriate credit to the original author(s) and the source, provide a link to the Creative Commons license, and indicate if changes were made.

\section{References}

Bauer S, Eisinger K, Wiest R, Karrasch T, Scherer MN, Farkas S, Aslanidis C, Buechler C (2012) Connective tissue growth factor level is increased in patients with liver cirrhosis but is not associated with complications or extent of liver injury. Regul Pept 179:10-14

Bovenschen N, Herz J, Grimbergen JM, Lenting PJ, Havekes LM, Mertens K, van Vlijmen BJ (2003) Elevated plasma factor VIII in a mouse model of low-density lipoprotein receptor-related protein deficiency. Blood 101:3933-3939

Cicha I, Garlichs CD, Daniel WG, Goppelt-Struebe M (2004) Activated human platelets release connective tissue growth factor. Thromb Haemost 91:755-760

Colak Y, Senates E, Coskunpinar E, Oltulu YM, Zemheri E, Ozturk O, Doganay L, Mesci B, Yilmaz Y, Enc FY, Kiziltas S, Ulasoglu C, Tuncer I (2012) Concentrations of connective tissue growth factor in patients with nonalcoholic fatty liver disease: association with liver fibrosis. Dis Markers 33:77-83

Dendooven A, Gerritsen KG, Nguyen TQ, Kok RJ, Goldschmeding R (2011) Connective tissue growth factor (CTGF/CCN2) ELISA: a novel tool for monitoring fibrosis. Biomarkers 16:289-301

Dziadzio M, Usinger W, Leask A, Abraham D, Black CM, Denton C, Stratton R (2005) N-terminal connective tissue growth factor is a marker of the fibrotic phenotype in scleroderma. QJM 98:485-492

Gao R, Brigstock DR (2003) Low density lipoprotein receptor-related protein (LRP) is a heparin-dependent adhesion receptor for connective tissue growth factor (CTGF) in rat activated hepatic stellate cells. Hepatol Res 27:214-220

Gao R, Brigstock DR (2004) Connective tissue growth factor (CCN2) induces adhesion of rat activated hepatic stellate cells by binding of its C-terminal domain to integrin alpha(v)beta(3) and heparan sulfate proteoglycan. J Biol Chem 279:8848-8855

Gerritsen KG, Peters HP, Nguyen TQ, Koeners MP, Wetzels JF, Joles JA, Christensen EI, Verroust PJ, Li D, Oliver N, Xu L, Kok RJ, Goldschmeding R (2010) Renal proximal tubular dysfunction is a major determinant of urinary connective tissue growth factor excretion. Am J Physiol Renal Physiol 298:F1457-F1464

Gerritsen KG, Abrahams AC, Peters HP, Nguyen TQ, Koeners MP, Den Hoedt C, Dendooven A, Van den Dorpel MA, Blankestijn P, Wetzels JF, Joles JA, Goldschmeding R, Kok RJ (2012) Effect of glomerular filtration rate on plasma $\mathrm{N}$-terminal connective tissue growth factor concentrations. Am J Kidney Dis 59:619-627

Gerritsen KG, Leeuwis JW, Koeners MP, Bakker SJ, van Oeveren W, Aten J, Tarnow L, Rossing P, Wetzels JF, Joles JA, Kok RJ, 
Goldschmeding R, Nguyen TQ (2015) Elevated urinary connective tissue growth factor in diabetic nephropathy is caused by local production and tubular dysfunction. J Diabetes Res 2015:539787

Gressner AM, Yagmur E, Lahme B, Gressner O, Stanzel S (2006) Connective tissue growth factor in serum as a new candidate test for assessment of hepatic fibrosis. Clin Chem 52:1815-1817

Gressner OA, Fang M, Li H, Lu LG, Gressner AM, Gao CF (2013) Connective tissue growth factor $(\mathrm{CTGF} / \mathrm{CCN} 2)$ in serum is an indicator of fibrogenic progression and malignant transformation in patients with chronic hepatitis B infection. Clin Chim Acta 421:126-131

Guo-Qiu W, Nai-Feng L, Xiao-Bo V, Linxian L, Chen Z, Lixia G, Zhao L (2010) The level of connective tissue growth factor in sera of patients with hepatitis B virus strongly correlates with stage of hepatic fibrosis. Viral Immunol 23:71-78

Herz J, Goldstein JL, Strickland DK, Ho YK, Brown MS (1991) 39-kDa protein modulates binding of ligands to low density lipoprotein receptor-related protein/alpha 2-macroglobulin receptor. J Biol Chem 266:21232-21238

Hollestelle MJ, Geertzen HG, Straatsburg IH, van Gulik TM, van Mourik JA (2004) Factor VIII expression in liver disease. Thromb Haemost 91:267-275

Honsawek S, Udomsinprasert W, Chirathaworn C, Anomasiri W, Vejchapipat P, Poovorawan Y (2013) Correlation of connective tissue growth factor with liver stiffness measured by transient elastography in biliary atresia. Hepatol Res 43:795-800

Kovalenko E, Tacke F, Gressner OA, Zimmermann HW, Lahme B, Janetzko A, Wiederholt T, Berg T, Muller T, Trautwein C, Gressner AM, Weiskirchen R (2009) Validation of connective tissue growth factor $(\mathrm{CTGF} / \mathrm{CCN} 2)$ and its gene polymorphisms as noninvasive biomarkers for the assessment of liver fibrosis. J Viral Hepat 16:612-620

Lillis AP, Van Duyn LB, Murphy-Ullrich JE, Strickland DK (2008) LDL receptor-related protein 1: unique tissue-specific functions revealed by selective gene knockout studies. Physiol Rev 88:887-918

Miyazaki O, Kurashita S, Fukamachi I, Endo K, Ng PS, Takehara K (2010) Subtraction method for determination of N-terminal connective tissue growth factor. Ann Clin Biochem 47:205-211

Moestrup SK, Gliemann J (1991) Analysis of ligand recognition by the purified alpha 2-macroglobulin receptor (low density lipoprotein receptor-related protein). Evidence that high affinity of alpha 2macroglobulin-proteinase complex is achieved by binding to adjacent receptors. J Biol Chem 266:14011-14017

Moestrup SK, Gliemann J, Pallesen G (1992) Distribution of the alpha 2macroglobulin receptor/low density lipoprotein receptor-related protein in human tissues. Cell Tissue Res 269:375-382

Muratoglu SC, Belgrave S, Hampton B, Migliorini M, Coksaygan T, Chen L, Mikhailenko I, Strickland DK (2013) LRP1 protects the vasculature by regulating levels of connective tissue growth factor and HtrA1. Arterioscler Thromb Vasc Biol 33:2137-2146
Narita M, Bu G, Olins GM, Higuchi DA, Herz J, Broze GJ Jr, Schwartz AL (1995) Two receptor systems are involved in the plasma clearance of tissue factor pathway inhibitor in vivo. J Biol Chem 270: 24800-24804

Panasiuk A, Prokopowicz D, Zak J, Matowicka-Karna J, Osada J, Wysocka J (2001) Activation of blood platelets in chronic hepatitis and liver cirrhosis P-selectin expression on blood platelets and secretory activity of beta-thromboglobulin and platelet factor- 4 . Hepato-Gastroenterology 48:818-822

Prakash J, Sandovici M, Saluja V, Lacombe M, Schaapveld RQ, de Borst MH, van Goor H, Henning RH, Proost JH, Moolenaar F, Keri G, Meijer DK, Poelstra K, Kok RJ (2006) Intracellular delivery of the p38 mitogen-activated protein kinase inhibitor SB202190 [4-(4fluorophenyl)-2-(4-hydroxyphenyl)-5-(4-pyridyl) $1 \mathrm{H}$-imidazole] in renal tubular cells: a novel strategy to treat renal fibrosis. J Pharmacol Exp Ther 319:8-19

Saenko EL, Yakhyaev AV, Mikhailenko I, Strickland DK, Sarafanov AG (1999) Role of the low density lipoprotein-related protein receptor in mediation of factor VIII catabolism. J Biol Chem 274:37685-37692

Sarafanov AG, Ananyeva NM, Shima M, Saenko EL (2001) Cell surface heparan sulfate proteoglycans participate in factor VIII catabolism mediated by low density lipoprotein receptor-related protein. J Biol Chem 276:11970-11979

Schwarz HP, Lenting PJ, Binder B, Mihaly J, Denis C, Dorner F, Turecek PL (2000) Involvement of low-density lipoprotein receptor-related protein (LRP) in the clearance of factor VIII in von Willebrand factor-deficient mice. Blood 95:1703-1708

Segarini PR, Nesbitt JE, Li D, Hays LG, Yates JR 3rd, Carmichael DF (2001) The low density lipoprotein receptor-related protein/alpha2macroglobulin receptor is a receptor for connective tissue growth factor. J Biol Chem 276:40659-40667

Verseput GH, Provoost AP, Braam BB, Weening JJ, Koomans HA (1997) Angiotensin-converting enzyme inhibition in the prevention and treatment of chronic renal damage in the hypertensive fawnhooded rat. J Am Soc Nephrol 8:249-259

Warshawsky I, Herz J, Broze GJ Jr, Schwartz AL (1996) The low density lipoprotein receptor-related protein can function independently from heparan sulfate proteoglycans in tissue factor pathway inhibitor endocytosis. J Biol Chem 271:25873-25879

Weitz S L, and WR Usinger 2003 Methods of assaying connective tissue growth factor. US patent (online) available at http://ip. com/patapp/US20030113816

Williams SE, Ashcom JD, Argraves WS, Strickland DK (1992) A novel mechanism for controlling the activity of alpha 2-macroglobulin receptor/low density lipoprotein receptor-related protein. Multiple regulatory sites for $39-\mathrm{kDa}$ receptor-associated protein. J Biol Chem 267:9035-9040

Zhang D, Wang NY, Yang CB, Fang GX, Liu W, Wen J, Luo C (2009) The clinical value of serum connective tissue growth factor in the assessment of liver fibrosis. Dig Dis Sci 55:767-774 